\title{
Influence of Chained Masonry on the Seismic Response of Reinforced Concrete Buildings
}

\author{
Abdelkader NOUR ${ }^{1, *}$, Abdelkader BENANANE ${ }^{1}$ and Humberto VARUM ${ }^{2}$ \\ ${ }^{1}$ Laboratory Materials and Processes of Construction, Faculty of Science and Technology, University of \\ Abdelhamid Ibn Badis, Route natoinale N 11, kharouba, 27000 Mostaganem, Algérie \\ ${ }^{2}$ CONSTRUCT-LESE, Department of Civil Engineering, Faculty of Engineering, University of Porto, \\ Porto 4200-465, Portugal
}

('Corresponding author's e-mail: abdelkader.nour@univ-mosta.dz)

Received: 29 September 2020, Revised: 21 February 2021, Accepted: 28 February 2021

\begin{abstract}
The influence of chained masonry walls, which represents a special case of masonry infill without gap, on the seismic response of reinforced concrete buildings is extremely important due to their wide use in this type of building. We can consider the period of building as the key parameter to study this influence. In this article, we had carried out a comparative study of several $2 \mathrm{D}$ models of a multi-storey reinforced concrete building with a brick chained masonry wall using the response spectrum method in the ETABS finite element software, following the prescriptions of the current Algerian seismic code. This study included the use of the number of spans, the span length, the number of storeys, the thickness of the chained masonry wall, the ground soft storey, the openings in the walls, and the short column for studying the influence of these to the walls. The values from the numerical simulation were compared with those from the formula of the period of building, provided by both the Algerian and European codes. Based on the results obtained, we were able to assess the influence of chained masonry walls on the seismic response on this type of buildings. Through this article, we have concluded that these walls have a great influence on the overall behavior of reinforced concrete buildings under seismic loading.
\end{abstract}

Keywords: Chained masonry wall, Seismic response, Reinforced concrete building, Period, ETABS

\section{Introduction}

The reinforced concrete buildings infilled with masonry walls are very well known in most parts of the world. It also represents in our country the majority of the urban heritage, especially in the north and in the highlands, which is generally known as areas very vulnerable to earthquakes. Here, we are concerned with the observation and study between these walls linked to frames without gap and the masonry walls, which is called "chained masonry walls" that is a special case of infill masonry [1,2].

Predicting the behavior of chained masonry walls is difficult, mainly because of the very varied characteristics of the components of these walls as well as the difficulty of knowing the paths of their deformations. Failure to properly construct these walls can lead to serious damage to the frames surrounding them. Also, the irregular distribution of chained masonry walls in the 3 main directions, be it length, width or height can lead to random behavior of these buildings and can lead to overall twisting. Furthermore, partially infilled frames can adversely affect the strength and rigidity of these buildings, especially if the openings in these walls are in direct contact with the columns where a short column phenomenon can form, thus, forming a very local dangerous stress [3-5].

The problems presented above, although few in number are mainly the result of the lack of a generally accepted seismic design methodology in the various international seismic codes, which has the 
influence that may result from these walls, as most codes currently available consider these walls as nonstructural elements, or take them into account with some simplifications [6-8].

The damage caused by the chained masonry walls by past earthquakes, especially recent ones, demonstrated the urgency of developing a methodology allowing to truly study the real behavior of these walls, and the extent of their influence on the buildings that they contain by presenting numerical and experimental models, and trying to simplify these approaches for designers in this field, so to use them in the design of new buildings to reduce the damage to these walls [12].

Always referring to what resulted from previous earthquakes as well as to various laboratory experiments prepared in this field, it was found that reinforced concrete buildings, fully or partially infilled with chained masonry walls behaved completely different from those without these walls when exposed to seismic loads. The fact that bare frames are less rigid and less resistant than fully or partially infilled walls. From this observation, it is evident that it is advantageous to take these walls into account in the modeling process $[3,9,11,12]$.

In recent years, several types of analytical models have been developed to fully understand the seismic behavior of these buildings infilled with chained masonry walls, and to approximately simulate their behavior. The infilled frames are usually made either of reinforced concrete or steel with brick, or concrete masonry. They are usually supplied as exterior walls [12].

In what follows, we will present a parametric study that we carried out by modeling several reinforced concrete frames in 2D using a finite element analysis program. We tried considering several factors and depending on the period of buildings as a basic criterion to study the influence of chained masonry walls on reinforced concrete buildings. After analyzing the results, we compared these with the empirical formulas of the 2 seismic codes (Algerian [14] and European [16]), then we draw conclusions to discover this influence based on different references in this area of study.

\section{Materials and methods}

\section{Description of structures}

Building forms and infill walls parameters

We had selected several multi-storey reinforced concrete 2D frames that include 3, 5, 7, 9, and 11 storeys (Figure 1).

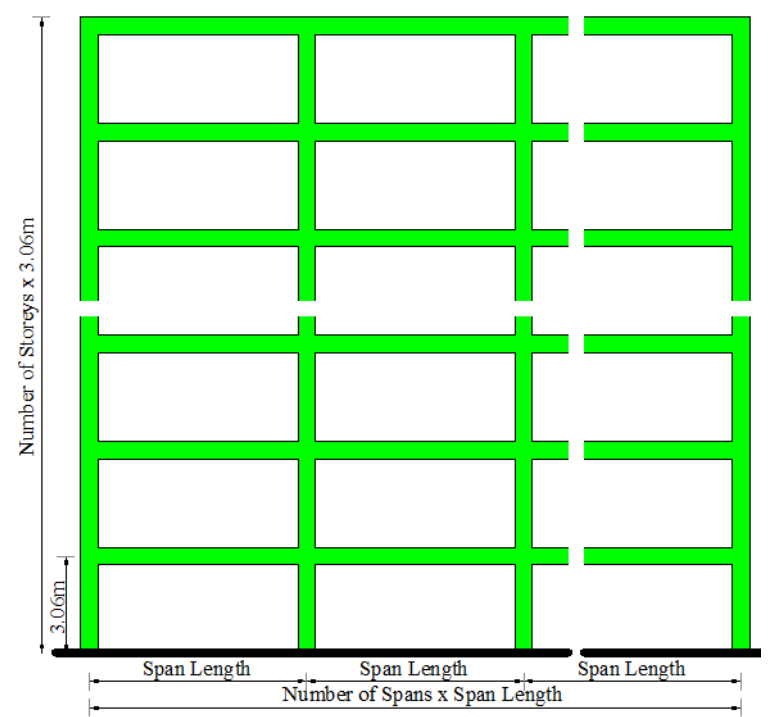

Figure 1 Geometric characteristics of a RC infilled frames. 
The storey's height of all the frames is fixed at $3.06 \mathrm{~m}$, considering the number of spans: 2, 4, and 6 . Besides, taking 4 lengths, which are 3, 4.5, 6, and $7.5 \mathrm{~m}$ to include the greatest number of dimensions, be it the number of spans, the length of each span and the total height of the building [3].

The bare frames were analyzed, in addition to their counterparts, that is to say the fully or partially infilled frames by the chained masonry walls [4], to know the influence of these walls on the periods of buildings and to note the differences which can occur depending on each of the factors used.

The main thicknesses of 15 and $25 \mathrm{~cm}$ were chosen for the chained masonry walls to mainly represent 2 types of walls, which are single and double leaf. The following percentages of openings were also used; ( $0 \%$ of openings) which represent bare frames, $(20 \%$ of openings) which represent partially infilled frames with a small percentage compared to the surface of the wall, and (50\% openings) which represents the partially infilled frames with a percentage representing half of the wall surface, and (100\% openings) which represents the fully infilled frames. In cognizance that the openings are caused by the phenomenon of the short column, which represent, respectively 20, 40 and $60 \%$ of the surface of the wall, and which are directly linked to the columns.

Moreover, the mechanical properties of the chained masonry walls used in the models to be analyzed, we relied on the properties of the red hollow bricks mentioned in the Algerian code of masonry, as they represent the majority of the masonry used in our country [13] (Table 1).

The building parameters used for the development of the models are listed in Table 1.

Table 1 Building parameters.

\begin{tabular}{ll}
\hline \multicolumn{1}{c}{ Parameter } & \multicolumn{1}{c}{ Value or type } \\
\hline Concrete strength & $25 \mathrm{MPa}$ \\
Modulus of elasticity of concrete, $\mathrm{E}_{\mathrm{c}}$ & $32164 \mathrm{MPa}$ \\
Steel tensile yield strength & $500 \mathrm{MPa}$ \\
Dead load & $6 \mathrm{kN} / \mathrm{m}^{2}$ \\
Live load & $1.5 \mathrm{kN} / \mathrm{m}^{2}$ \\
Number of storey & $3,5,7,9,11$ \\
Building height & $9.18,15.3,21.42,27.54$ and $33.66 \mathrm{~m}$ \\
Span length & $3,4.5,6$ and $7.5 \mathrm{~m}$ \\
Number of span & $2,4,6$ \\
Masonry compressive strength, $\mathrm{f}_{\mathrm{m}}$ & $2.0 \mathrm{MPa}$ \\
Modulus of elasticity of masonry, $\mathrm{E}_{\mathrm{m}}$ & $2000 \mathrm{MPa}$ \\
Thickness of infill walls, $\mathrm{t}_{\mathrm{m}}$ & 150 and $250 \mathrm{~mm}$ \\
Masonry wall opening percentage & $0 \%$ (fully infilled), 20, 50, 100\% (bare frame) \\
\hline
\end{tabular}

\section{Design of structures}

In this study, we fully relied on the Algerian seismic code (RPA2003), to analyze all the different types of frames, using the Extended 3D (3-Dimensional) Analysis of Building Systems (ETABS) finite element software, and considering the response spectrum method, recommended by this code. The seismic zone chosen is the zone with high seismicity (III), the behavior factor " $q$ " being the value 3.5 , the user group is 2 and the type of soil is the soft soil "S2". The properties of the materials widely used in Algeria, which make up the elements used in this study were also utilized (Table 1). For the loads applied 
in the analysis of these frames, the following loads were retained; the dead load is $6 \mathrm{kN} / \mathrm{m}^{2}$ and the live load is $3.5 \mathrm{kN} / \mathrm{m}^{2}$. [14,15]

For the beams, they have a section of $30 \times 30 \mathrm{~cm}^{2}$ for the $3 \mathrm{~m}$ span, $30 \times 40 \mathrm{~cm}^{2}$ for the $4.5 \mathrm{~m} \mathrm{span}$, $30 \times 50 \mathrm{~cm}^{2}$ for the $6 \mathrm{~m} \mathrm{span}$, and $30 \times 60 \mathrm{~cm}^{2}$ for the $7.5 \mathrm{~m} \mathrm{span}$. Moreover, the sections of the columns, decrease by $5 \mathrm{~cm}$, all 3 storeys except for the 3-storey frames which have the same $40 \times 40 \mathrm{~cm}^{2}$ section. The frames of 11 storeys start with $60 \times 60 \mathrm{~cm}^{2}$ and end with $45 \times 45 \mathrm{~cm}^{2}$, the frames of 9 storeys start with $55 \times 55 \mathrm{~cm}^{2}$ and end with $45 \times 45 \mathrm{~cm}^{2}$, the frames of 7 storeys start with $50 \times 50 \mathrm{~cm}^{2}$ and end with $40 \times 40$ $\mathrm{cm}^{2}$, the frames of 5 storeys start with $45 \times 45 \mathrm{~cm}^{2}$ and end with $40 \times 40 \mathrm{~cm}^{2}$.

\section{Modeling}

\section{General details}

Regarding the modeling process, we used the spectral response method adopted in the current Algerian seismic code, using the ETABS finite element software, which uses the best-known method among structural analysis softwares. We also have considered 2D bares frames with the previously mentioned dimensions. Whereas, the period of the buildings was considered to be one of the most important criteria for studying the seismic behavior of these buildings, with the following factors being taken into account namely, the number of spans, the length of the spans, the number of storeys, the thickness of the chained masonry wall, the ground soft storey, the openings in the walls and the short column $[19,20]$.

In addition to the geometric and mechanical characteristics of the materials and sections of elements constituting these frames used and mentioned above, all the dead loads, on top of the $20 \%$ of the live loads, were used as seismic masses according to the current Algerian seismic code [14].

\section{Modeling and validation}

Chained masonry walls modeling

To model the chained masonry walls, we relied on the "wall" finite element, recommended by the ETABS software to represent the walls. It differs from some other software, which uses the element "shell", to represent both the slab and the wall as the same, without seeing the big difference between them in terms of general behavior [16].

\section{Validation of model}

To validate the models studied by the ETABS software, we used the famous SEISMOSTRUCT software, which offers a large capacity to model the infill masonry walls. We have modeled several frames with the 2 thicknesses mentioned above and considering the partially and fully infilled frames. After that, the same frames were modeled using ETABS software and compared its with the results given by SEISMOSTRUCT software. The outcome showed a great convergence between the 2 software in terms of the period of building. This allowed us to use the models proposed, and generalize them to additional models with the factors mentioned previously, and always according to the period of the building $[15,17]$.

\section{Results and discussion}

Influence of number of spans on the period of building

To study the influence of the number of spans on the period of the building and by comparing the neglect and the chained masonry consideration, we analyzed Table $\mathbf{2}$ and Figure 2, which mainly represents the study of 2D frames for a 7-storey reinforced concrete building, with the number of spans between 2, 4 and 6 with a span length of $4.5 \mathrm{~m}$ for each span. The chained masonry thickness is 0.15 and $0.25 \mathrm{~m}$, respectively and after analyzing the results, we can observe the following:

If we exclude the formulas of both the European and the Algerian codes, which are affected neither by the absence nor by the presence of the chained masonry walls, we observed very clearly that the values of the periods in the fully infilled frames, whether 15 or $25 \mathrm{~cm}$ thick, decreased considerably compared to bare frames. As an example, we compared the fully infilled frame of 6 spans and $25 \mathrm{~cm}$ thick masonry, 
with the bare frame of the same type, we found that the values for the period have decreased by over $67 \%$. This clearly indicates that the modeling of chained masonry walls contributed by a significant percentage to reduce the values of the period, which inevitably leads to an increase in the strength and stiffness of the building.

It should also, be noted, that the modeling of the chained masonry walls, contributes to the decrease of the period values of the building, and these values continue to decrease as the number of spans increases. Besides, it gives the building excellent behavior in the face of seismic loadings. On the other hand, by neglecting the modeling chained masonry walls, the building loses much of its stiffness that is needed to withstand seismic loadings.

Further, the frames whether bare or fully infilled were not significantly affected by the increase or decrease in the number of spans except for a small decrease as the number of spans increases. Meanwhile, we found that the values of the periods in fully infilled frames, whether they were 15 or $25 \mathrm{~cm}$ in thickness, decreased considerably compared to bare frames. This clearly indicates that the modeling of the chained masonry walls significantly contributed to reducing the values of the period, which inevitably leads to an increase in the strength and stiffness of the building.

Table 2 Influence of number of spans on the period of building.

\begin{tabular}{cccccc}
\hline $\begin{array}{c}\text { Number } \\
\text { of storey }\end{array}$ & Bare frame & $\begin{array}{c}\text { Fully infilled } \\
\text { by 0.15 }\end{array}$ & $\begin{array}{c}\text { Fully infilled } \\
\text { by 0.25 }\end{array}$ & RPA2003 & EC8 \\
\hline 2 & 0.944 & 0.395 & 0.337 & 0.835 & 0.747 \\
4 & 0.951 & 0.377 & 0.315 & 0.591 & 0.747 \\
6 & 0.953 & 0.371 & 0.308 & 0.482 & 0.747 \\
\hline
\end{tabular}

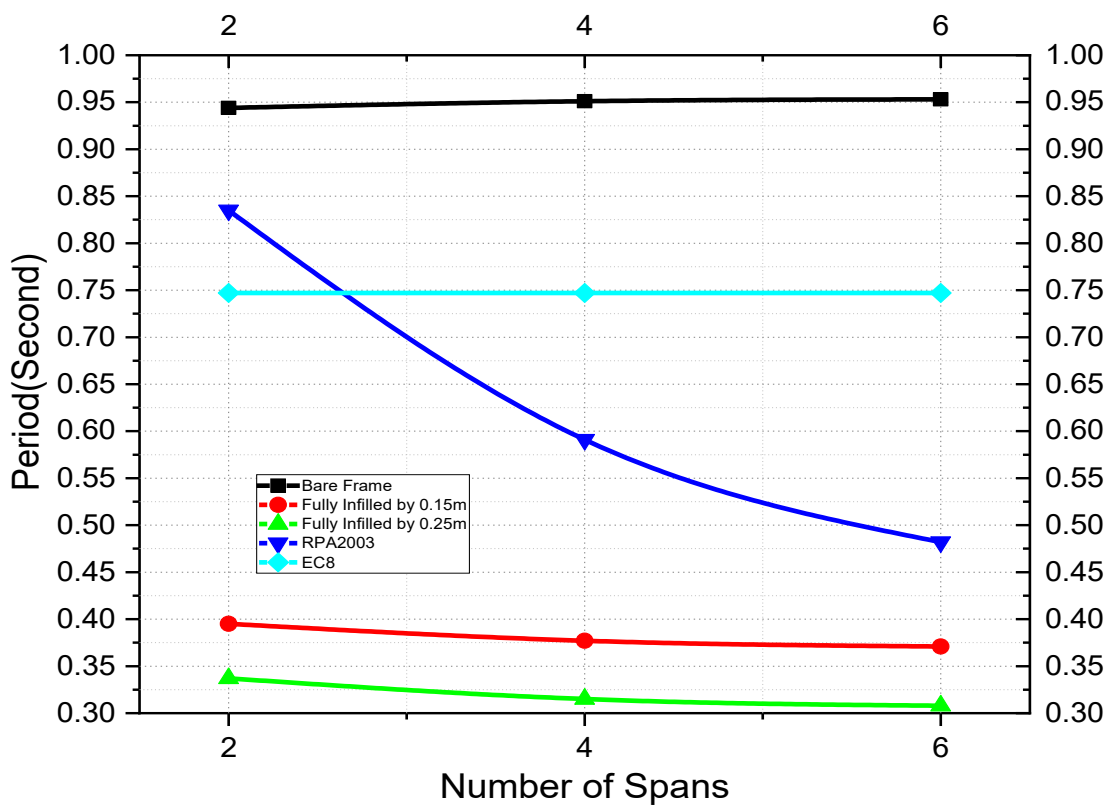

Figure 2 Influence of number of spans on the period of building. 


\section{Influence of span length on the period of building}

To study the influence of span length on the period of buildings by comparing neglect and construction considerations with chained masonry walls, we analyzed Table $\mathbf{3}$ and Figure 3, which basically represents a study of several 2D frames for a building of 7-storey with 4 spans considering the span length between 3, 4.5, 6 and $7.5 \mathrm{~m}$. The thickness of the chained masonry walls is $0.25 \mathrm{~m}$. After analysis, we can note the following:

If we exclude the formulas of both the European and the Algerian codes, which are affected neither by the absence nor by the presence of the chained masonry walls, the integration of the chained masonry walls, in the modeling led to a significant reduction in the period values, which makes this observation very important. For example, if we compare the fully infilled frames with a thickness of $25 \mathrm{~cm}$ for masonry and a span length of $7.5 \mathrm{~m}$, with the same bare frames, we found that the values of the period are reduced by more than $67 \%$. Under other conditions, the period values did not show any significant change, with the modification of the span length values.

It must be noted here that the presence of the chained masonry walls in the analytical models, has considerably contributed to reduce the values of the periods of the building, and thus allows the building to increase its stiffness and resistance, which gives the building excellent seismic behavior and good response to seismic loadings. Conversely, failure to model these walls can result in a loss of additional strength and stiffness which can tolerate the building to better withstand such forces.

Except for the Algerian seismic code, which showed that there is an inverse relationship between the span length and the values of the frames period, the span length did not have a significant influence, either on the formula of the European seismic code, the fully infilled frames or as bare.

Increasing the span length dramatically decreases the building period values, especially for fully infilled frames. Then, a positive relationship was observed between the values of the period of the building and the length of the span.

Table 3 Influence of span length on the period of building.

\begin{tabular}{ccccc}
\hline Span length & Bare frame & Fully infilled by $\mathbf{0 . 2 5} \mathbf{~ m}$ & RPA2003 & EC8 \\
\hline 3 & 0.934 & 0.315 & 0.723 & 0.747 \\
4.5 & 0.951 & 0.315 & 0.591 & 0.747 \\
6 & 0.960 & 0.315 & 0.512 & 0.747 \\
7.5 & 0.970 & 0.317 & 0.458 & 0.747 \\
\hline
\end{tabular}

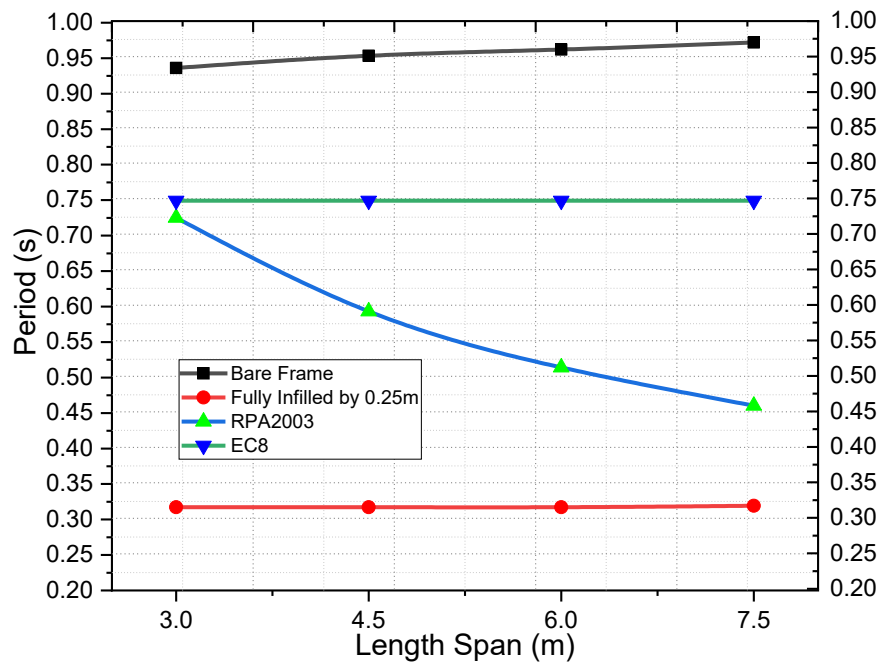

Figure 3 Influence of span length on the period of building. 


\section{Influence of number of storeys on the building period}

To study the influence of the number of storeys for a reinforced concrete building, we analyzed several 2D frames consisting of 3, 5, 7, 9 and 11 storeys with fixing the number of spans at 4 spans and the span length of each span is $4.5 \mathrm{~m}$, through exposed and other fully infilled frames with thickness chained masonry walls equal to 0.15 and also $0.25 \mathrm{~m}$, depending on the period of the building.

Based on the results presented in both Table 4 and Figure 4, we can note the following:

If we exclude the formulas of both the European and the Algerian codes, which are affected neither by the absence nor by the presence of the chained masonry walls. Here, too, it can be concluded that a comparison of fully infilled frames with bare frames of the same type, showed a significant decrease in the values of the period, and all this is due to the introduction of chained masonry walls in the modeling process. For example, if we took a fully infilled frame of 11 storeys with $25 \mathrm{~cm}$ thickness for the masonry, and we compared it to the same frame, but it is bare, we find that the period values have decreased by more than $65 \%$, which is a significant percentage indicating the magnitude of the change that these walls caused. From the recorded results, it can be derived that the chained masonry walls were a direct cause of the decrease in the values of the periods compared to the bare frames, and thus they led to a significant increase in resistance and stiffness of the buildings. This observation focused our attention on the need to include these walls in the modeling process to better understand the behavior of buildings of this type as a whole, in order to reduce the influence of seismic loadings on them.

An increase in the number of storeys greatly increases the period values of the building. It should be noted here that the integration of the chained masonry walls in the modeling of the frames very clearly reduces the values of the period of the building. In this regard, we have noticed a big difference between bare and fully infilled frames.

Table 4 Influence of number of storeys on the period of building.

\begin{tabular}{cccccc}
\hline $\begin{array}{c}\text { Number of } \\
\text { storey }\end{array}$ & Bare frame & $\begin{array}{c}\text { Fully infilled } \\
\text { by } \mathbf{0 . 1 5} \text { m }\end{array}$ & $\begin{array}{c}\text { Fully infilled } \\
\text { by 0.25 }\end{array}$ & RPA2003 & EC8 \\
\hline 3 & 0.448 & 0.172 & 0.141 & 0.253 & 0.396 \\
5 & 0.703 & 0.273 & 0.226 & 0.422 & 0.580 \\
7 & 0.951 & 0.377 & 0.315 & 0.591 & 0.747 \\
9 & 1.199 & 0.483 & 0.407 & 0.759 & 0.902 \\
11 & 1.446 & 0.592 & 0.501 & 0.928 & 1.048 \\
\hline
\end{tabular}

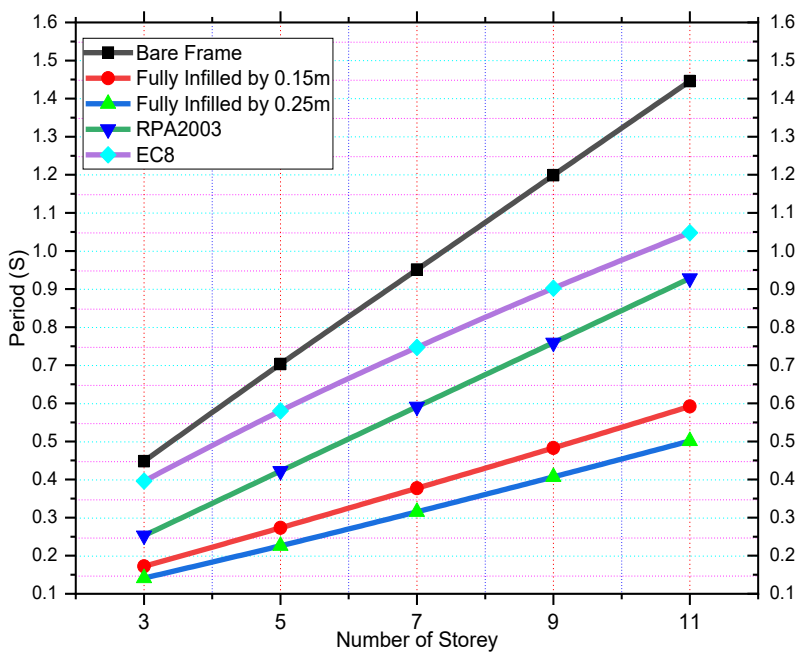

Figure 4 Influence of number of storeys on the period of building. 


\section{Influence of chained masonry thickness on the building period}

To study the influence of the chained masonry walls thickness of a multi-storey reinforced concrete building, we analyzed several 2D frames of 3, 5, 7, 9 and 11 storeys with fixing the number of spans by 4 and the span length of each interval are $4.5 \mathrm{~m}$, through exposed bare frames and others fully infilled frames with a masonry thickness of $15 \mathrm{~cm}$ as well as $25 \mathrm{~cm}$ depending on the period of the building.

Based on the results presented in both Table 5 and Figure 5, we can note the following:

If we exclude the formulas of both the European and the Algerian codes, which are affected neither by the absence nor by the presence of the chained masonry walls, without going into the question of the decrease in period values in the case of fully infilled frames compared to bare frames of the same type, we note that there is an inverse relationship between the thickness of the chained masonry walls and the values of periods. Therefore, the greater the thickness of the wall, the lower the values of the periods, and vice versa.

These results, confirmed the need to incorporate chained masonry walls into the modeling of these buildings and the damage that can be caused by neglect of these walls when evaluating the behavior of buildings to withstand seismic loads. This situation imposes on the designer not to neglect the modeling of these chained masonry walls, because of the importance of knowing the real seismic behavior of these buildings and to exploit to the maximum the resistance and the stiffness which they bring to address well the seismic loadings.

The modeling of the chained masonry walls, with a thickness of $15 \mathrm{~cm}$, made it possible to reduce the values of the period of the building, in addition to those of a thickness of $25 \mathrm{~cm}$, which presented values compared to the $1^{\text {st }}$ thickness which is relatively weak, without forgetting the big difference recorded between them and the bare frames.

Table 5 Influence of chained masonry thickness on the period of building.

\begin{tabular}{cccccc}
\hline $\begin{array}{c}\text { Number } \\
\text { of storey }\end{array}$ & Bare frame & $\begin{array}{c}\text { Fully infilled } \\
\text { by 0.15 }\end{array}$ & $\begin{array}{c}\text { Fully infilled } \\
\text { by 0.25 }\end{array}$ & RPA2003 & EC8 \\
\hline 3 & 0.448 & 0.172 & 0.141 & 0.253 & 0.396 \\
5 & 0.703 & 0.273 & 0.226 & 0.422 & 0.580 \\
7 & 0.951 & 0.377 & 0.315 & 0.591 & 0.747 \\
9 & 1.199 & 0.483 & 0.407 & 0.759 & 0.902 \\
11 & 1.446 & 0.592 & 0.501 & 0.928 & 1.048 \\
\hline
\end{tabular}

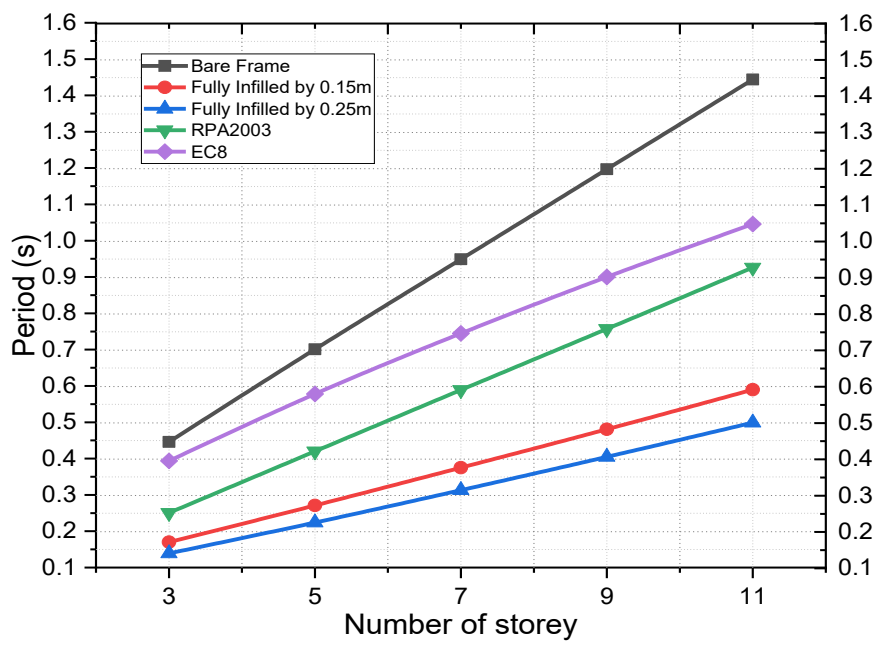

Figure 5 Influence of chained masonry thickness on the period of building. 


\section{Influence of ground soft storey on the building period}

To study the effect of the soft ground storey of a reinforced concrete building, we analyzed several frames consisting of 3, 5, 7, 9 and 11 storeys, fixing the number of spans with 4 spans and the span length of each frame is $4.5 \mathrm{~m}$. Through exposed bare frames and others fully infilled frames with a masonry thickness of $25 \mathrm{~cm}$, depending on the period of the building, and others are completely infilled, except for the ground storey, which sometimes differs from the rest of the storeys, and all of these depend on the period of the building.

Based on the results presented in both Table 6 and Figure 6, we can note the following:

If we exclude the formulas of both the European and the Algerian codes, which are affected neither by the absence nor by the presence of the chained masonry walls.

Reagrding the issue of the ground soft storey, we can often approach it in such buildings for several reasons which compelled us to study the influence of this situation, albeit in a simple way. It has been observed through the results that the presence of ground soft storey in the partially infilled frames has a relative influence on the values of the period because we recorded a significant increase in these values compared to the fully infilled frames. It can also be seen that the presence of ground soft storey affects at low altitude and its influence is less when at high altitude.

The presence of the ground soft storey, has been adversely affected by the strength and stiffness of buildings, and can sometimes cause serious damage to buildings of this type and can be a real test for buildings against seismic loadings. This inevitably leads us to think about the process of the uniform distribution of the chained masonry walls along with the height of the building, since the non-uniform distribution of these walls can cause a sudden change in the stiffness and resistance of the building to such charges.

The presence of the ground soft storey in partially infilled frames has a better response than bare frames, which indicates the importance of modeling the chained masonry walls.

Table 6 Influence of ground soft storey on the period of building.

\begin{tabular}{cccc}
\hline Number of storey & Bare frame & Fully infilled by $\mathbf{0 . 2 5} \mathbf{~ m}$ & Ground soft story \\
\hline 3 & 0.448 & 0.141 & 0.271 \\
5 & 0.703 & 0.226 & 0.331 \\
7 & 0.951 & 0.315 & 0.393 \\
9 & 1.199 & 0.407 & 0.465 \\
11 & 1.446 & 0.501 & 0.545 \\
\hline
\end{tabular}

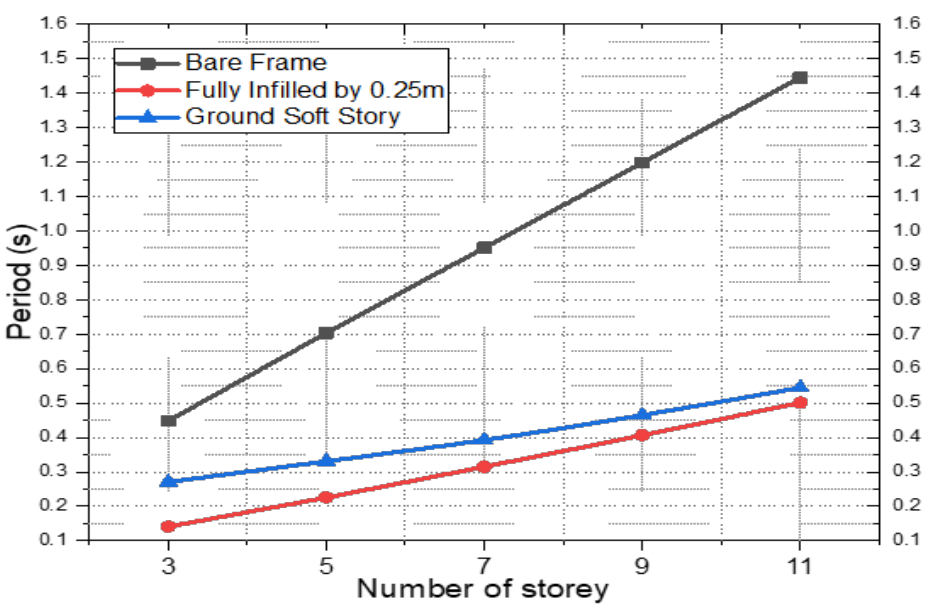

Figure 6 Influence of ground soft storey on the period of building. 


\section{Influence of masonry openings on the building period}

As part of the study of the influence of openings in the chained masonry walls of a multi-storey reinforced concrete building, we analyzed several 2D frames of 3, 5, 7, 9 and 11 storeys, with the number of spans fixed at 4 spans, and $4.5 \mathrm{~m}$ in span length of each span. Using bare frames and other fully infilled frames, with $25 \mathrm{~cm}$ thick chained masonry walls. Additinally, the infilled frames, which contain openings in the chained masonry walls at of 20 and $50 \%$, due to the presence of openings in chained masonry walls cannot be overlooked in these buildings, and it all depends on the period of the buildings.

In light of the results presented in both Table 7 and Figure 7, we can note the following:

The fact that the chained masonry walls contain openings of varying sizes cannot be ignored, that is why we have studied the influence of these openings in varying proportions on the response of partially infilled frames and compared them to those which are fully infilled and to those bared. We have found that the higher the opening rate, the higher is the period values of the frames. Despite all this, it was found that the modeling of the partially infilled frames significantly contributed to the reduction of the values of the construction period compared to the cases of bare frames.

It should also be noted that increasing the aperture ratios negatively affects the strength and stiffness of the building, and inevitably places it in a critical position against seismic loadings. For example, if we take the 11-story fully infilled frame, and compare it to its counterpart, which contains $50 \%$ of the wall chained masonry, we clearly notice that the building period values have been increased by about $42 \%$.

This shows the negative influence of the size of the openings on the seismic behavior of the frames. Also, it can draw our attention and give us a general idea of the damage that can be caused to buildings when exposed to seismic loadings due to the presence of these openings, especially in large proportions.

The inclusion of openings in the chained masonry walls, with varying proportions, increased the period values of the building compared to fully infilled frames. It has been observed that there is a direct relationship between the opening ratios and the building period values, but regardless of the opening ratios, partially infilled frames showed better response compared to bare frames, because of the presence of the chained masonry walls.

Table 7 Influence of masonry openings on the period of building.

\begin{tabular}{ccccc}
\hline $\begin{array}{c}\text { Number } \\
\text { of storey }\end{array}$ & $\begin{array}{c}\text { 0 \% Opening } \\
\text { (Fully infilled) }\end{array}$ & $\mathbf{2 0} \%$ Opening & $\mathbf{5 0} \%$ Opening & $\begin{array}{c}\text { 100\% Opening } \\
\text { (Bare frame) }\end{array}$ \\
\hline 3 & 0.141 & 0.183 & 0.263 & 0.448 \\
5 & 0.226 & 0.293 & 0.411 & 0.703 \\
7 & 0.315 & 0.401 & 0.564 & 0.951 \\
9 & 0.407 & 0.517 & 0.716 & 1.199 \\
11 & 0.501 & 0.635 & 0.868 & 1.446 \\
\hline
\end{tabular}

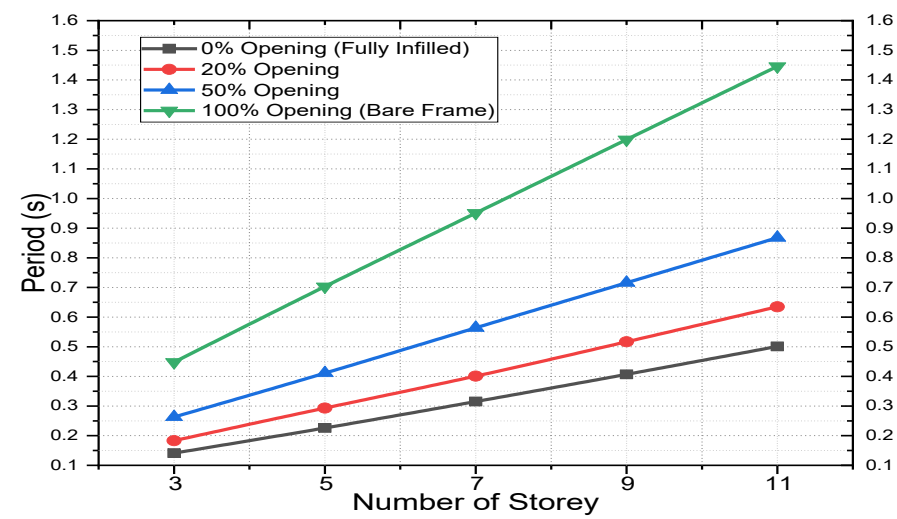

Figure 7 Influence of masonry openings on the period of building. 


\section{Influence of short column on the building period}

To study the influence of the short column of a reinforced concrete building, we analyzed several frames consisting of 3, 5, 7, 9 and 11 storeys, fixing the number of spans with 4 spans and the span length of each frame is $4.5 \mathrm{~m}$. Through exposed bare frames and others fully and partially infilled frames with a masonry thickness of $25 \mathrm{~cm}$, depending on the period of the building.

Based on the results presented in both Table 8 and Figure 8, we can note the following:

In this area, we have studied another case, which is strongly present in many reinforced concrete buildings and others. We are obliged to deal with this important case, which is the phenomenon of the short column. Based on the results, it can be said that this phenomenon contributed negatively to the increase in period values of buildings, which requires less strength and stiffness of the building and can weaken it against seismic loads.

It can also be said that this is a special type of opening in the chained masonry walls, but it is directly connected to the columns and this is what directly affects the columns. We have also noticed that there is a direct relationship between the size of the opening connected to the columns and the values of the period of the frames, so the smaller the size of the opening, the higher is the height of the exposed low column, and the lower the period values of frames.

It must also be said that the partially infilled frames due to the phenomenon of the short column in the largest size of openings, recorded a significant decrease compared to these bare frames, due to the presence of chained masonry walls, which gave the buildings additional strength and stiffness, indicating the importance of modeling these walls.

With the existence of the phenomenon of short columns in the modeling of partially infilled frames, it is evident that the modeling of the chained masonry walls there is a high tendency of negatively affecting the values of the period of building, therefore there is an inverse relationship between them.

Table 8 Influence of short column on the period of building.

\begin{tabular}{cccccc}
\hline $\begin{array}{c}\text { Number } \\
\text { of stories }\end{array}$ & Bare frame & $\begin{array}{c}\text { Fully infilled } \\
\text { by } \mathbf{0 . 2 5} \mathbf{~ m}\end{array}$ & $\begin{array}{c}\text { Short column } \\
\mathbf{2 0} \%\end{array}$ & $\begin{array}{c}\text { Short column } \\
\mathbf{4 0} \%\end{array}$ & $\begin{array}{c}\text { Short column } \\
\mathbf{6 0} \%\end{array}$ \\
\hline 3 & 0.448 & 0.141 & 0.151 & 0.189 & 0.251 \\
5 & 0.703 & 0.226 & 0.241 & 0.290 & 0.372 \\
7 & 0.951 & 0.315 & 0.335 & 0.395 & 0.493 \\
9 & 1.199 & 0.407 & 0.433 & 0.501 & 0.612 \\
11 & 1.446 & 0.501 & 0.534 & 0.610 & 0.734 \\
\hline
\end{tabular}

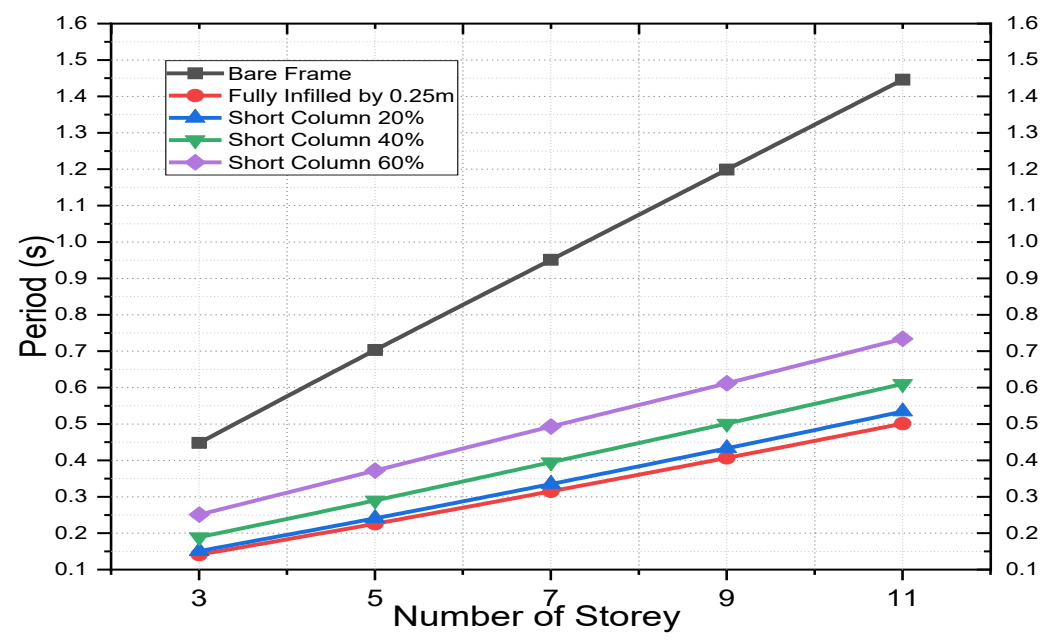

Figure 8 Influence of short column on the period of building. 


\section{Conclusions}

Based on the above, we draw the attention of various designers to the need to integrate the modeling of these walls into the numerical models of buildings, to better understand the behavior of these buildings in the instance of seismic loadings. This can significantly contribute in increasing the strength and stiffness of the building on the one hand, and improving the study of the behavior of these buildings in response to seismic loadings.

We have come to conclude that the neglect of the chained masonry walls in the process of modeling reinforced concrete buildings can lead to a false study of this type of buildings.

For further investigation in this research axis, we recommend introducing these walls in the simulation operation explicitly to properly represent the masonry, and to compare the real behavior of reinforced concrete buildings infilled by masonry in the light of seismic loadings.

\section{Acknowledgments}

The research program reported in this paper was sponsored by the Construction Materials and Processes Laboratory (CMPL), Faculty of Science and Technology University of Mostaganem, Algeria.

\section{References}

[1] M Ferraioli and A Lavino. Irregularity effects of masonry infills on nonlinear seismic behaviour of RC buildings. Math. Probl. Eng. 2020; 2020, 4086320.

[2] MM Abdelaziz, MS Gomma and H El-Ghazaly. Seismic evaluation of reinforced concrete structures infilled with masonry infill walls. Asian J. Civ. Eng. 2019; 20, 961-81.

[3] L Cavaleri, PG Asteris, CC Repapis and EV Repapi. Fundamental period of infilled reinforced concrete frame structures. 2017; 13, 929-41.

[4] MM Abdelaziz, M Gomaa and H El-ghazaly. Effect of unreinforced masonry infill walls on seismic performance. Open Civ. Eng. J. 2017; 11, 919-31.

[5] ME Ahmad, N Ahmad, S Pervez, A Iqbal, AZ Khan, ME Rahim, W Hassan, K Umer and K Khan. Seismic performance evaluation of modern bare and masonry-infilled RC SMRF structures. 2019; 2019, 6572465.

[6] P Christou and C Venizelou. The contribution of the infill walls to the lateral strength of concrete frames. Open. Construct. Build. Tech. J. 2019; 13, 114-22.

[7] FEMA 306. Evaluation of earthquake damaged concrete and masonry wall buildings: Basic procedures manual. FEMA, Washington DC, 1998.

[8] F Christiana, N Kyriakides, CZ Chrysostomou and E Georgiou. Finite element model of masonryinfilled RC frame. In: Proceedings of the $16^{\text {th }}$ European Conference on Earthquake Engineering, Thessaloniki, Greece. 2018.

[9] AR Amalia and D Iranata. Comparative study on diagonal equivalent methods of masonry infill panel. 2017; 1855, 030011.

[10] A Banik and L Halder. Period formula for reinforced concrete buildings with infill walls. 2016; 857, 177-82.

[11] PG Asteris, CC Repapis, F Foskolos, A Fotos, AK Tsaris. Fundamental period of infilled RC frame structures with vertical irregularity. Struct. Eng. Mech. 2017; 61, 663-74.

[12] S Shan, S Li, MM Kose, H Sezen and S Wang. Effect of partial infill walls on collapse behavior of reinforced concrete frames. Eng. Struct. 2019; 197, 109377.

[13] RD E Design, ET DE Calculation, and DE S Masonry, C 2.45 rules for the design and calculation of masonry.

[14] C National and DER Appliquee. Rules parasismiques algeriennes RPA 99 / version 2003. 2003.

[15] CSI Analysis Reference Manual, Avaliable at: https://wiki.csiamerica.com/display/doc/CSI+ Analysis+Reference+Manual, accessed May 2020.

[16] NF En. Eurocode 8, norme européenne. 2005.

[17] Seismosoft. SeismoStruct 2018 user manual. 2018. 